\title{
Professional English Teaching Practice for Electronics Specialty
}

\author{
Jin Zhou, Zhihua Hu, Haihui Song, and Guanling Chen \\ School of Electronic and Electrical Engineering \\ Shanghai Second Polytechnic University \\ Shanghai, 201209, P. R. China \\ zhoujin@ee.sspu.cn
}

\begin{abstract}
This paper examines the existing problems in professional English teaching practice in engineering colleges, especially for electronics specialty. In order to further improve the teaching quality, measures involving four aspects - course setup, teaching methods, course contents, and performance evaluation are discussed. The practical usage of professional English should be the core content of teaching reform.
\end{abstract}

Keywords- Professional English; Electronics Specialty; Teaching Practice

\section{INTRODUCTION}

In the globalized world, English is the international language tool for communication in academics, business, and all walks of life. At present, undergraduates of engineering majors are exposed to more English information than ever either in grasping the new trend of technological development or interacting with foreigners in future career. According to a 2009 survey conducted by Beijing Higher Education Graduates Career Center, two out of eight qualities highlighted by potential employers are related to communication skills: One is strong ability to communicate and congeniality; the other one is team spirit and cooperation skills ${ }^{[1]}$. Therefore, sufficient technical knowledge and solid English language base are necessary for future technical personnel.

The overall objective of college professional English teaching is that students should improve their listening, reading comprehension and speed, as well as their translating ability of English materials in related engineering field. On the one hand this course is a continual study of English; on the other hand, its content covers the advanced technology in specialized field. Therefore, both English skills and specialized knowledge are required for learning this course ${ }^{[2]}$.

It is noticeable that professional English appears in various forms such as academic papers, technical reports, scientific and educational books, product specifications, user manuals, e-learning courses and so on ${ }^{[3]}$. Apparently, to serve the purpose of efficient idea exchange in technical field, the learning process should be associated these related activities. Thus, the teaching practice should start from analyzing and understanding the main features of professional English, then move on to the practical usage of professional English, both oral and written. From our former teaching experience, we concluded the problems in course teaching and organization and proposed a series of improvement measures. The details were given in this paper.

\section{COURSE SETUP AND BASIC REQUIREMENTS}

The course Professional English is usually taught on the 5th semester for engineering major students in a four-year bachelor course plan. At this time, students have finished their college English study and most of them have passed CET4 (College English Test Band 4), which means they have gained a good foundation for advanced English study. During this course, students should enhance their abilities of listening comprehension, reading comprehension, writing technical documents and acquiring up to date technological information related to their specialization. Course requirements are as follows:

1) Students should master high-frequency specialized vocabulary words and expressions.

2) Students should learn to understand, translate technical materials accurately at moderate speed.

3) Students should get familiar with career related English communication, including resume, technical writing, etc.

\section{TEACHING METHOD REFORM}

Teaching is a continuously improving process. From lessons in recent years we summarized 3 problems:

Firstly, most teaching materials of similar professional English courses were highly specialized. Each major has its own professional English textbook. The teacher spent a lot of time on explaining the technological knowledge. However, the basic terms common to all engineering majors did not receive adequate attention. For example, how to pronounce commonly used symbols in formulas and equations, such as + (plus), - (minus), * (times), $\propto$ (proportional), < (less than), $\int$ (integral). The same circumstances happen to the physics terms, such as torque, moment, angular speed, net force, magnetic field. In practice, however, the common ground for professional English is more important. After all, the translation skills for each major are the same.

Secondly, most course materials are written in formal English and are excerpts from English textbooks. The other forms of English materials are usually ignored. There is a gap between the course materials and the practical English used. The course contents and auxiliary teaching methods are obviously less attractive than the college English courses.

The third problem was that there were not enough interactive practices in either translating or writing. Some students are relying on the electronic dictionaries or online translating tools. After so many years of English learning, 
students still can not follow instructions given by a user guide in English on their own. Also, a lot of errors can be found when they write resumes and other technical documents.

All these problems initiate us to take measures to improve the teaching quality of "Professional English". To address these problems, we put forward the following proposals:

1) Shift the emphasis to students' practical English competence, i.e. both the English translating skills and the technological background knowledge.

2) Conduct interactive and multimedia teaching instead of teachers' one-way teaching and students' passive learning.

3) Conceive more realistic assignments including resume, introduction to the major, introduction to a laboratory, abstract of an article, etc.

\section{COURSE CONTENTS}

A suitable textbook meeting all the course requirements is difficult to find. Some textbooks are just a collection of excerpts of books in English. Some textbooks discussed grammar rules in details which bored the non-English major students quickly. Also, the professional English textbooks seldom have auxiliary audio files, attractive multimedia courseware like college English textbooks do. Therefore, the meticulous selection of course contents is the key to teaching professional English well.

For these reason, we draw up a new course plan with emphasis on practical English competence. The whole course includes 8 units, 6 class hours each. The details are shown in Table 1 . The exercises are designed to improve students' comprehensive ability of using English ${ }^{[4-6]}$.

These exercises challenge students to recall what they learned in college English, practice new terms and get familiar with usage of specialized English. In this way, teacher could deepen students' understanding of theoretical knowledge, encourage independent thinking and enhance their communication ability. All the exercises' contents and forms are closely related practical technical English. Furthermore, large space is left for students to demonstrate their creativity and mastery of language.

As interest is the best teacher, throughout the teaching process, we should create a lively atmosphere in the classroom and stimulate students' interests in learning. In each unit, the application of translation skills is intertwined with the text content. Also, students' participation in the classroom teaching is very important. Detailed explanation of typical errors occurred in exercises can be illuminating for all the students.

TABLE 1. NEW COURSE Plan OF "Professional ENGLiSh FOR EleCtronics SPECIALty”

\begin{tabular}{|c|c|c|c|c|}
\hline Units & Contents & Translation Skills & Exercises & $\begin{array}{c}\text { Class } \\
\text { Hours } \\
\end{array}$ \\
\hline Electrical Circuits & $\begin{array}{l}\text { - Main electrical elements } \\
\text { Laws describing the relationships } \\
\text { between currents and voltages }\end{array}$ & The features of professional English & Resume & 6 \\
\hline $\mathrm{AC}$ & $\begin{array}{l}\text { - Three-phase circuits } \\
\text { - Wye-connection and delta connection }\end{array}$ & Criteria for a good translation & $\begin{array}{l}\text { Translation of letters, } \\
\text { notices or emails }\end{array}$ & 6 \\
\hline $\begin{array}{l}\text { The Operational } \\
\text { Amplifier }\end{array}$ & $\begin{array}{ll}\bullet & \text { Ideal Op-Amp } \\
- & \text { Two Op-Amp laws }\end{array}$ & $\begin{array}{l}\text { Commonly used mathematic symbols } \\
\text { and formula }\end{array}$ & Introduction to the major & 6 \\
\hline Transistors & $\begin{array}{ll}- & \text { Semiconductor } \\
- & \text { Configurations } \\
- & \text { Transistor shape }\end{array}$ & $\begin{array}{l}\text { Understand and translate according } \\
\text { to context }\end{array}$ & $\begin{array}{l}\text { Translation of a section of } \\
\text { user guide }\end{array}$ & 6 \\
\hline $\begin{array}{l}\text { Logical Variables } \\
\text { and Flip-flop }\end{array}$ & $\begin{array}{ll}\text { - } & \text { Logical variables and Boolean algebra } \\
\text { - } & \text { Flip-flops }\end{array}$ & Word order adjustment & Sample of “Call for paper” & 6 \\
\hline Control Theory & $\begin{array}{ll}- & \text { Transfer function } \\
- & \text { Laplace Transformation }\end{array}$ & $\begin{array}{l}\text { Comparison of the grammar habits of } \\
\text { English and Chinese }\end{array}$ & Introduction to a laboratory & 6 \\
\hline $\begin{array}{l}\text { Computer } \\
\text { Technology }\end{array}$ & $\begin{array}{ll}\bullet & \text { Computer Organization } \\
\bullet & \text { Operating System } \\
\bullet & \text { Applications }\end{array}$ & $\begin{array}{c}\text { Transformational techniques of parts } \\
\text { of speech }\end{array}$ & $\begin{array}{l}\text { Translation of a section of } \\
\text { software document }\end{array}$ & 6 \\
\hline PLC Overview & $\begin{array}{ll}- & \text { PLC Architecture } \\
\bullet & \text { Operation } \\
- & \text { Programming }\end{array}$ & $\begin{array}{l}\text { Understand and translate long } \\
\text { sentences }\end{array}$ & Abstract for an article & 6 \\
\hline Total & & & & 48 \\
\hline
\end{tabular}




\section{PERFormance EVAluation}

In view of the practicability of the course, we do not want to encourage the phenomena of cramming for final. Therefore, the performance evaluation system is changed. The overall score consists of daily performance score (30\%) and a final test score (70\%). The daily performance score is assessed through 3 aspects: attendance (5\%), class behavior (5\%) and assignments (20\%). The final test is given out in open-book form. Students can bring a paper dictionary for reference. They are asked to do reading comprehension and translation of technical documents within limited time. No electronic dictionaries or mobile phones are allowed.

After the teaching reform, the attendance rate increases apparently, reaching 95\%. And the feedback from students is also positive. Improvements can be perceived from every aspect, ranging from students' attitude towards study, the assignments, and students' consciousness of studying, to students' translating and writing ability. This course also prepares the students for literature reading and thesis abstract writing.

\section{SUMMARY}

Based on the problems we identified during teaching the course "Professional English for Electronics Specialty", we proposed several measures and implemented them in the subsequent teaching practice. With the new course plan, the engineering students are encouraged to use English under possible practical scenarios. As a result, it is observed that the enthusiasm of student's learning initiative is aroused and students' comprehensive English competence is enhanced.
However, in the future, there are still a lot left to improve and accomplish in the teaching practice. More multimedia teaching materials can be introduced to enrich the classroom activities. Group work should be encouraged. Also, current performance evaluation weights more on reading and writing capabilities than speaking and listening capabilities. In order to foster competitive students, we have to overcome these problems.

\section{ACKNOWLEDGMENT}

This work was supported by the Leading Academic Discipline Project of Shanghai Municipal Education Commission (No. J51801).

\section{REFERENCES}

[1] Y, Luo, Technical Communication Skills, Publishing House of Electronics Industry, Beijing, China, 2011.

[2] S. Huan, T. Yan, The Reform of Professional English Teaching in the Major of Electronic Information, 2011 2nd International Conference on Education and Educational Technology (EET 2011), Chengdu, China, October 1-2, pp. 217-222, 2011.

[3] W. Jiang, W. Hu, F. Yuan, Reform and Practice of Professional English Teaching, 2010 ETP/IITA Conference on Telecommunication and Information (TEIN 2010) Proceedings, June 22-23, Kuala Lumpur, Malaysia, p73-75, 2010.

[4] H. Wang, Specified English for Automation (Second Edition), China Machine Press, Beijing, China, 2008.

[5] W. Dai, Professional English for Electronics Specialty, Tsinghua University Press, Beijing, China, 2011.

[6] X. Zhu, Q. Zhang, X. Gu, Practical Professional English in Electrical Engineering (Second Edition), Tsinghua University Press, Beijing, China, 2012. 